\title{
A koronária-CT-angiográfia jelentősége a mindennapi gyakorlatban stabil anginás betegek körében
}

\author{
Drobni Zsófia Dóra, Kolossváry Márton, Szilveszter Bálint, Merkely Béla, \\ Maurovich-Horvat Pál
}

\begin{abstract}
MTA-SE Lendület Kardiovaszkuláris Képalkotó Kutatócsoport,Semmelweis Egyetem, Városmajori Szív- és Érgyógyászati Klinika, Budapest
\end{abstract}

Levelezési cím: Dr. Maurovich-Horvat Pál, e-mail: maurovich.horvat@gmail.com

\begin{abstract}
A kardiovaszkuláris megbetegedések világszerte vezetik a mortalitási és morbiditási statisztikákat. A nagy kockázatú betegek korai azonosítása kiemelt jelentőséggel bír.

A koronária-CT-angiográfia (CTA) egyre jelentősebb szerepet tölt be a stabil anginás betegek kivizsgálásában. Kiváló negatív prediktív értékének köszönhetően fő indikációs területe a kis és közepes kardiovaszkuláris rizikóval rendelkező betegek esetén a koszorúér-betegség jelenlétének kizárása.

A szív-CT-vizsgálat során, a natív felvételeken meghatározhatjuk a kalcium-score értékét, amely kiváló független prediktora a kardiovaszkuláris eseményeknek. A koronária-CTA-felvételek pedig lehetővé teszik a lumen és a koronária plakkok ábrázolását, amely segítségével a lumenszükületek és a koszorúérplakkok mennyisége nagy pontossággal meghatározhatók.

A betegség jelentlétének kizárása, vagy a koronária-betegség kiterjedtségének meghatározása fontos szereppel bír a mellkasi panaszokkal rendelkező betegek vizsgálatában.

Az összefoglalóban kitérünk a különböző nemzetközi ajánlásokban fellelhető különbségekre. Az elkövetkező néhány évben a koronária-CTA-vizsgálatok száma nagy valószínűséggel jelentősen emelkedik majd és tovább erősödik az invazív angiográfia vizsgálatot megelőző „kapuőr” szerepe.
\end{abstract}

Kulcsszavak: koronária-CT-angiográfia, stabil angina, kalcium-score, ateroszklerotikus plakk

The role of Coronary CT angiography in patients with stable angina, in the rutine clinical practice

Cardiovascular diseases are the leading cause of mortality and morbidity worldwide. Coronary CT angiography (coronary (TA) is a robust non-invasive diagnostic tool in the work up of patients with stable angina. With its high negative predictive value, coronary CTA is and excellent tool to rule out the presence of coronary artery disease in patients with low to intermediate risk.

Ca-score can be assesed on ECG-gated native cardiac scans and it provides an excellent independent tool for prognostication. The coronary lumen and wall can be visualized by coronary CTA, which allows for plaque characterization and quantification.

Coronary CTA has an important role to guide management strategies of patients with chest pain. The European and American guidelines give slightly different recommendations for the use of coronary calcium score and coronary CTA in patients with chest pain. The number of coronary CTA exams will increase during the upcoming years, and this imaging modality will play an imprtant role as a gatekeeper of catheterisation in individuals with suspected coronary artery disease.

Keywords: Coronary CT angiography, stable angina, calcium-score, coronary plaque 
A koronária-CT-angiográfia (koronária-CTA) fő indikációs területe a koszorúér-betegség kizárása kis és közepes rizikójú betegek körében (1). Az Európai Kardiológus Társaság ajánlása alapján a koronária-CTA a stabil anginás, $15-50 \%$ pre-teszt probabilitással (PTP) rendelkező betegek számára ajánlott (1. táblázat) (2). A vizsgálat magas negatív prediktív értékkel rendelkezik, tehát amennyiben a koronária-CTA során koszorúér-betegség nem ábrázolódik, a mellkasi panaszok hátterében koszorúér-betegség nagy biztonsággal kizárható (3). A koronária-CTA a kis és közepes rizikóval rendelkező betegeknél az iszkémia-provokációs tesztek alternatívája lehet.

\section{Kalcium-score vizsgálat}

EKG-kapuzott natív szív-CT-vizsgálat segítségével meghatározható a koszorúerek plakk-terheltségét leíró kalcium-score (Ca-score) érték. A natív vizsgálat során a koszorúerekben lévő meszes plakkok mennyiségéről kapunk információt, amelyet az Agatston-féle Ca-score metódussal számszerüsíthetünk szemiautomatikus szoftver segítségével (4). A meszesedések területét a CT-denzitással való súlyozást követően a szoftver Ca-score értékké alakítja, amely jó korrelációt mutat a koszorúerekben jelen lévő teljes plakktömeggel. A Ca-score a nemkívánt kardiovaszkuláris események független prediktora (2. táblázat) $(5,6)$. Az utóbbi évek során több munkacsoport is igazolta, hogy panaszmentes betegek körében a Ca-score=0 kitűnő negatív kardiovaszkuláris rizikómarker, segít azonosítani azokat a betegeket, akiknél nem, vagy kevésbé indokolt a gyógyszeres prevenciós kezelés (7). Megemlítendő

1. TÁBLÁZAT. Klinikai preteszt probabilitás (PTP) a stabil mellkasi fájdalommal jelentkező betegeknél az Európai Kardiológiai Társaság (ESC) ajánlása alapján. A fehér színnel jelölt pre-teszt probabilitással rendelkező betegek esetében a stabil koszorúér-betegség valószínűsége kisebb mint 15\%, ezért további vizsgálatok nélkül kezelhetők. A kék színnel jelölt betegek esetében, terheléses EKG-vizsgálat ajánlott kiindulásként, illetve noninvazív iszkémia-tesztek jönnek szóba, ha azok elérhetők. A sárga színnel jelölt kategóriába tartozó betegeknél noninvazív funkcionális vizsgálat ajánlott. A piros, magas pre-teszt probabilitással rendelkező betegek esetében stabil koszorúér-betegség jelenléte igen valószínū, rizikóbecslés szükséges.

\begin{tabular}{|l|c|c|c|c|c|c|} 
& \multicolumn{2}{c}{$\begin{array}{c}\text { Típusos } \\
\text { angina }\end{array}$} & \multicolumn{2}{c}{$\begin{array}{c}\text { Atípusos } \\
\text { angina }\end{array}$} & \multicolumn{2}{c|}{$\begin{array}{c}\text { Nem specifi- } \\
\text { kus fájdalom }\end{array}$} \\
\hline Életkor & Férfi & Nö & Férfi & Nö & Férfi & Nö \\
\hline $30-39$ & 59 & 28 & 29 & 10 & 18 & 5 \\
\hline $40-49$ & 69 & 37 & 38 & 14 & 25 & 8 \\
\hline $50-59$ & 77 & 47 & 49 & 29 & 34 & 12 \\
\hline $60-69$ & 84 & 58 & 59 & 28 & 44 & 17 \\
\hline $70-79$ & 89 & 68 & 69 & 37 & 54 & 24 \\
\hline$>80$ & 93 & 76 & 78 & 47 & 65 & 32 \\
\hline
\end{tabular}

2. TÁBLÁZAT. Ca-score értékek és a hozzájuk tartozó rizikókategóriák, valamint a relatív halálozási rizikók $(5,6)$

\begin{tabular}{|c|c|c|c|}
\hline $\begin{array}{l}\text { Ca-score } \\
\text { érték }\end{array}$ & $\begin{array}{l}\text { Meszes } \\
\text { koszorúér- } \\
\text { plakkok }\end{array}$ & $\begin{array}{c}\text { Szív- } \\
\text { infarktus } \\
\text { kockázat }\end{array}$ & $\begin{array}{l}\text { Relatív } \\
\text { halálozási } \\
\text { rizikó }\end{array}$ \\
\hline 0 & $\begin{array}{c}\text { Nem } \\
\text { mutatható ki }\end{array}$ & & 1,31 \\
\hline $1-10$ & $\begin{array}{c}\text { Kis } \\
\text { mennyiségben }\end{array}$ & Kicsi & 1,48 \\
\hline $11-100$ & Több & $\begin{array}{c}\text { Enyéh } \\
\text { emelkedett }\end{array}$ & 3,61 \\
\hline $101-400$ & $\begin{array}{c}\text { Közepes } \\
\text { mennyiségben }\end{array}$ & $\begin{array}{l}\text { Közepes- } \\
\text { magas }\end{array}$ & 3,84 \\
\hline$>400$ & $\begin{array}{c}\text { Nagy } \\
\text { mennyiségü }\end{array}$ & Magas & 5,78 \\
\hline
\end{tabular}

továbbá, hogy a Ca-score mérése növeli a statinterápiával kapcsolatos compliance-t (8). A közepes rizikóval rendelkező egyének körében a Ca-score erősebb prognosztikai értékkel rendelkezik, mint a carotis intima-media vastagság, boka-kar index, a CRP-érték vagy a pozitív családi anamnézis $(9,10)$.

A több mint 5000 randomizált beteget számláló Multi-Ethnic Study of Atherosclerosis (MESA) vizsgálatban statint korábban nem kapó betegeket követtek medián 7,6 évig és vizsgálták a kardiovaszkuláris események alakulását. Azon betegeknél, akiknél a Ca-score $\geq 100$ volt (21\%), a kardiovaszkuláris események gyakorisága 22,7-29,5/1000 fő volt. Azon betegeknél pedig, akiknél maximálisan egy lipidparaméterben volt eltérés, az események gyakorisága alacsonyabb, 2,7-5,9/1000 fő volt. Azon egyéneknél, akiknél egyik lipidparaméterben sem volt eltérés, de a Ca-score $\geq 100$ volt, több esemény történt, mint abban a csoportban, ahol mindhárom lipidparaméter (LDL $\geq 3,36 \mathrm{mmol} / \mathrm{l}, \mathrm{HDL}<1,03 \mathrm{mmol} / \mathrm{l}$ férfiaknál vagy $\mathrm{HDL}<1,29 \mathrm{mmol} / \mathrm{l}$ nőknél, triglicerid $\geq 1,69 \mathrm{mmol} / \mathrm{l}$ ) emelkedett volt, de a Ca-score=0 volt. Mindezek alapján felmerül a Ca-score szerepe a személyre szabott statinterápia beállításában, azonban ennek megerősítése további klinikai vizsgálatokat igényel (11).

Kiemelendő azonban, hogy a Ca-score értéke a koszorúér-szűkület mértékével nem mutat szoros öszszefüggést, tehát magas Ca-score nem jár feltétlenül obstruktív koronáriabetegséggel (legalább egy szegmentumon $>50 \%$ lumenszúkület), ugyanakkor az alacsony Ca-score sem zárja ki az obstruktív betegséget. A Ca-score $=0$ értékkel rendelkező betegek 12\%-nál azonosítható koszorúér-betegség, és ezen betegek közül minden tizedik esetben obstruktív koronáriabetegség igazolható (12). Az utóbbi esetekben a nem kalcifikált ateroszklerotikus plakkok állnak a háttérben, ezért azok a natív felvételen nem ábrázolódnak (1. ábra). Ezt tükrözi az Európai Kardiológus Társaság stabil koszorúér-betegség vizsgálatáról szóló ajánlása (2013), amely a Ca-score mérését nem ajánlja (III C) a koszorúér-szűkület diagnosztizálására (1).

Amennyiben a beteg anamnézisében beszűkült vesefunk- 


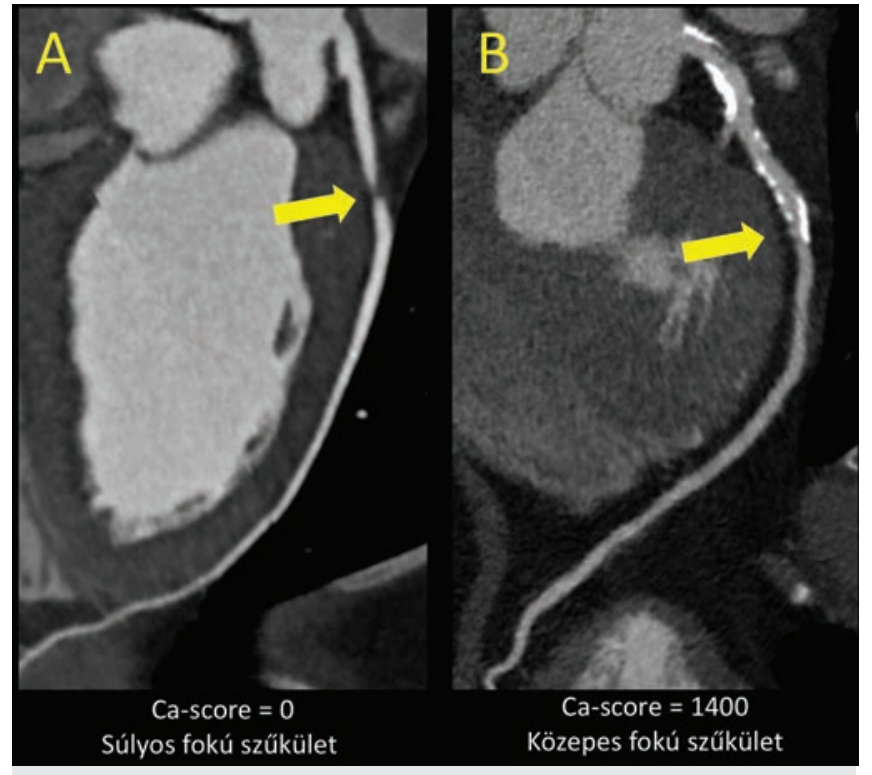

1. ÁBRA. „A" panelen Ca-score $=0$ értékkel rendelkező beteg, súlyos fokú szűkülettel. „B” panelen egy magas, Ca-score=1400 értékkel rendelkező beteg, akinél súlyos fokú lumenszükület nem ábrázolódott a kontrasztanyag adás után végzett CT-angiográfián

ció (GFR<60 ml/perc/1,73 m²) vagy kontrasztanyag-allergia szerepel, a kalcium-score vizsgálatot követően a koronária-CT-angiográfia elvégzését mérlegelni szükséges.

\section{Koronária-CT-angiográfia}

A koronária-CTA során nem csupán a meszesedések ábrázolódnak, hanem a koronáriák lumene, az érfal és a szívüregek is megítélhetővé válnak. A vizsgálat magas szenzitivitása (95-99\%) és magas negatív prediktív értéke (97-99\%), kitűnő vizsgálati módszerré teszi a kis és közepes rizikójú betegek körében a koszorúér-betegség kizárása terén $(3,13)$. Fontos azonban figyelembe venni, hogy a koronária-CTA ionizáló sugárterheléssel és jódos kontrasztanyag adásával jár. A vizsgálat megfelelő indikáció alapján végezhető csak el. Széles körben a Diamond-Forrester-módszer szerint kerül meghatározásra a preteszt probabilitás. Továbbá az esetleges relatív vagy abszolút kontraindikációk (veseelégtelenség GFR<60 ml/perc/1,73 m², kontrasztanyagallergia) kizárását követően a diagnosztikus felvételt befolyásoló tényezők (obesitas, légzéstartási nehézség, ritmuszavarok) ismeretében mérlegelni szükséges a vizsgálat indokoltságát és megfontolni más diagnosztikai eljárás alkalmazását (14).

A koronária-CTA inkonklúzív stressz-tesztet követően Ila osztályú C-szintű ajánlással javasolt, tehát a vizsgálat elvégzése megfontolandó. Csakúgy, mint azoknál a betegeknél, akiknél a stressz-teszt kontraindikált. Szintén Ila, C-indikáció vonatkozik azokra az egyénekre, akiknél kis-közepes preteszt probabilitás áll fenn és valószínűsít- hetően diagnosztikus CT-képminőség érhető el, így ebben a populációban a koronária-CTA a stressz-teszt alternatívája lehet. A koronária-CTA elvégzése panaszmentes egyénekben, koszorúér-betegség gyanúja nélkül, szürés jelleggel nem ajánlott (III. C). Emellett magas (>50\%) PTP esetén, illetve sztentek vizsgálata esetén a koronária-CTA egyéni mérlegelés tárgyát képezi (1).

\section{Plakkmorfológia}

A koronária-CTA során ábrázolódott koszorúér-plakkokat morfológiájuk és mennyiségük alapján is jellemezhetjük. A vizsgálat során az obstruktív (>50\% szükület) és nem obstruktív ( $<50 \%$ szükület) plakkok is nagy pontossággal ábrázolódnak (15). A koronária-CTA szubmilliméteres térbeli felbontóképessége, valamint a CT-denzitáson alapuló szöveti karakterizálás lehetővé teszi az egyes plakk-komponensek jellemzését és így megkülönböztethetünk kalcifikált, részben kalcifikált és nem kalcifikált plakkokat (16). Ezen csoportokon belül azonosíthatunk nagy rizikóra utaló plakkjellegzetességeket, komponenseket (17). Ilyen komponens a szemcsés kalcium, az alacsony CT-denzitás, a napkin ring jel, valamint a pozitív remodelláció (2. ábra) $(18,19)$.

A szemcsés kalcium definíciója alatt a $3 \mathrm{~mm}$-nél kisebb átmérőjü, >130 HU denzitást mutató plakk-komponenseket értjük, amelyeket nemkalcifikált komponens vesz körül. Alacsony CT-denzitású komponensekről (<60 HU), ex vivo vizsgálatokkal bizonyították, hogy azok zsírdús plakkokat jelölnek, továbbá a vékonysapkás fibroatheromákban is jelen van alacsony CT-denzitású komponens (20). A napkin ring jel a nem kalcifikált plakkokra jellemző mintázat. Ekkor a plakk középső részén alacsony attenuációjú terület figyelhető meg, amelyet gyűrűszerüen magasabb attenuaciójú terület határol. A napkin ring jel specificitása kiváló a magas kockázatú plakkok és a vékonysapkás fibroatheromák azonosítása terén (21). Pozitív remodelláción az érfal plakkokat tartalmazó szakaszának kompenzatorikus kitágulását értjük, ezáltal a lumenátmérő nem változik, szignifikáns szűkület nem alakul ki, így a betegnél panaszok nem jelentkeznek. Ezeknek a plakk-jellegzetességeknek a jelenléte a nagy kardiovaszkuláris rizikóval társul $(15,22)$. Motoyama és munkatársai 27士10 hónapos után követéses vizsgálatában az akut koronária-szindrómát szenvedett egyének korábban készült koronária-CTA-felvételeit elemezték. Az akut koronária szindróma kockázata nagyobb volt azoknál az egyéneknél, akiknél pozitív remodellációt és alacsony denzitást mutató plakk volt megfigyelhető (23).

\section{Koszorúér-plakkterheltség}

A koszorúér-plakkterheltség számításához számos szemikvantitatív és kvantitatív módszer áll rendelkezésünkre. A leggyakrabban alkalmazott plakkterheltséget 


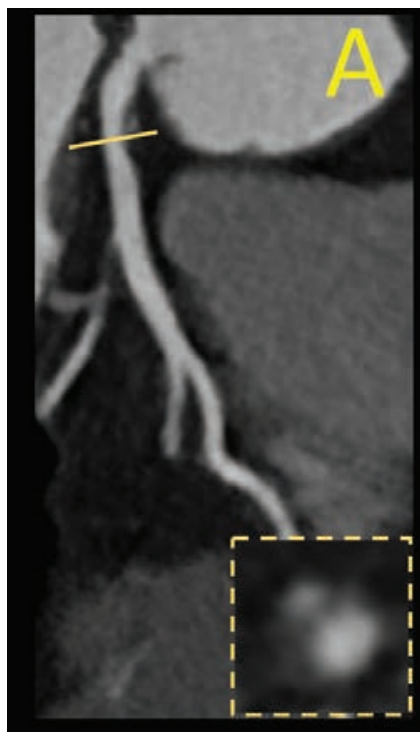

Pozitív remodelláció

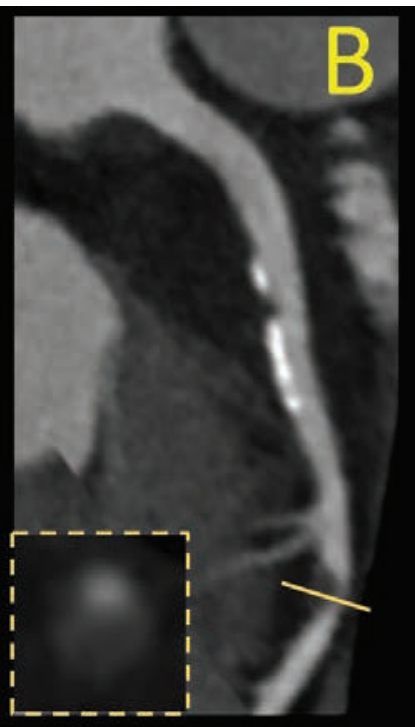

Alacsony denzitás

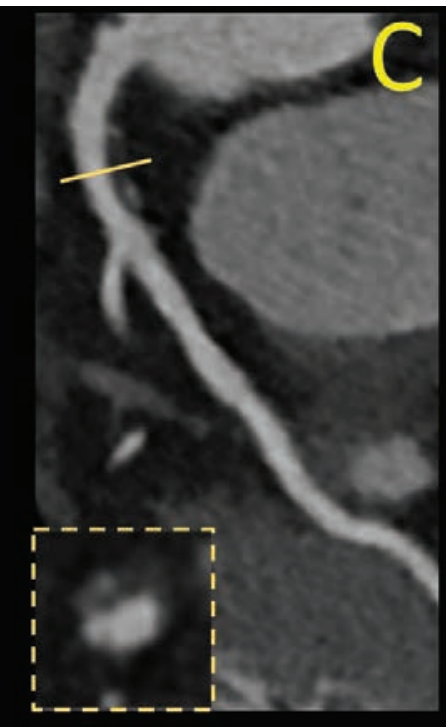

Napkin ring jel

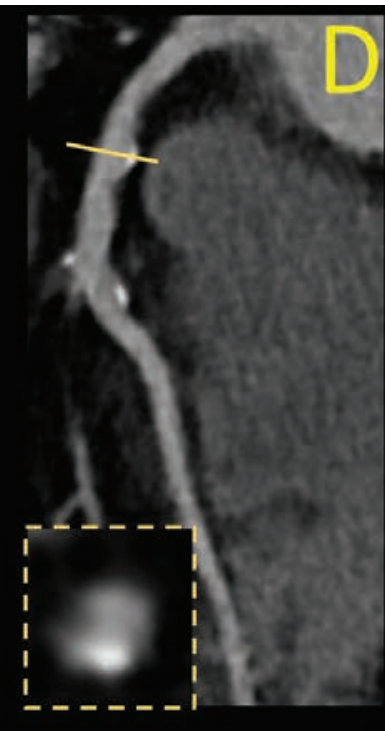

Szemcsés kalcium

2. ÁBRA. Demonstratív ábra a nagy rizikójú plakk-komponensekről

leíró pontrendszer számítása az ateroszklerotikus plakkokkal rendelkező koronária-szegmentumok összegén alapul. Az összeadás során figyelmen kívül hagyjuk, hogy egy adott szegmentumon milyen fokú szűkület ábrázolódik. Az így számított értéket, „szegmentum érintettség pontszám”-nak nevezzük. Következő lépésben, már beszámítjuk a lumenszűkület mértékét, minimális fokú szűkülettől az elzáródott szegmentumig 5 pontos skálát használunk, és megkapjuk a „szegmentumszükület pontszám"-ot. Ezek az egyszerüen számítható, plakkterheltséget jellemző pontszámok a kardiovaszkuláris események erős, független prediktorai (24). Bittencourt és munkatársai több mint háromezer koronária-CTA-vizsgálaton átesett beteget követett négy évig és az ábrázolódott koszorúér-betegség függvényében vizsgálták a kardiovaszkuláris események arányát. Eredményük alapján, azon betegek akiknél a koszorúér-betegség kiterjedtnek bizonyult (több mint 4 szegmentum érintett), de egyik szegmentumban sem volt obstruktív betegség, magasabb kardiovaszkuláris rizikóval rendelkeztek, mint azon egyének akiknél a koszorúér-betegség nem volt kiterjedt (kevesebb mint 4 szegmentum érintett), de valamelyik szegmentumon jelen volt obstuktív betegség. Tehát a lumenszükület (obstruktív vagy nem obstruktív) mértékétől függetlenül a jövőbeli kardiovaszkuláris események számát nagyban meghatározza a betegséggel érintett koszorúér-szegmentumok száma, a betegség kiterjedtsége (25). Minél több plakk található a koszorúérrendszerben, annál nagyobb eséllyel lesz jelen egy nagy kockázatú plakk is, aminek következtében a jövőbeni kardiovaszkuláris esemény valószínűsége megnő.

A koronária-CTA során a negatív lelet is hordoz információt. Több mint 1300 koronária-CTA-vizsgálaton át- esett beteg 4 év 4 hónapos utánkövetése során egyáltalán nem történt kardiovaszkuláris esemény azoknál a betegeknél, akiknél a vizsgálat koszorúér-betegség jelenlétét kizárta. Elmondhatjuk tehát, hogy egy negatív eredményű koronária-CTA minimum négy kardiovaszkuláris eseménytől mentes évet jelent (26).

\section{Koronária-CTA vezérelte terápia}

A koronária-CTA-vizsgálatok egyharmadában a lelet alapján a koszorúér-betegség kizárható, a felvételen szűkület vagy plakk nem ábrázolódik. Ilyen esetben további megerősítő vizsgálatok nem szükségesek (3. táblázat) (27). A vizsgálati alanyok harmada-fele esetében non-obstruktív szűkületet okozó koszorúér-betegség található. A CT alapján non-obstruktív betegcsoportban a terápia indokoltsága egyelőre nincs alátámasztva randomizált vizsgálatokkal. Olyan non-obstruktív betegek esetében, akiknél a betegség kiterjedt (több mint 4 koronária-szegmentum érintett), statinterápia mellett a kardiovaszkuláris halálozás és a miokardiális infarktusok száma csökkenést mutatott, ezért a mindennapi gyakorlatban ebben a populációban a statinterápia indítását javasoljuk, függetlenül a vér lipidértékektől $(28,29)$. Amennyiben obstruktív betegséget találtak a koronária-CTA során és a beteg optimális gyógyszeres terápia mellett is típusos panaszokról számol be, invazív kardiológiai konzílium javasolt.

Puri és munkatársai a koszorúér-plakkok változását vizsgálta nagy dózisú, standard dózisú statinnal és statinnal nem kezelt egyénekben. Csupán a nagy dózisú statinnal kezelt csoportban figyelték meg plakktérfogat regresszióját $(0,6 \pm 0,1 \%)$, azonban a plakkok kalciumtartalma mindhárom csoportban növekedett. 
3. TÁBLÁZAT: A koronária-CTA lelete alapján javasolt teendők és mérlegelendő beavatkozások $(37,38)$

\section{Koronária-CTA lelet}

Nincs eltérés vagy minimális koszorúér-betegség tív (<50\% szükület) koszorúér-betegség

Nem nagy kockázatú obstruktív (>50\% ér-betegség
Kiterjedt nem obstrukszűkület) koszorú-
Nem koszorúér eredetű etiológia megfontolandó

Terápia a primer prevenciós ajánlások alapján

Életmódbeli változtatások, statin, aszpirin

Életmódbeli változtatások, statin, aszpirin

Iszkémia elleni gyógyszeres terápia a panaszok csökkentése érdekében Funkcionális vizsgálat a hemodinamikai szituáció tisztázása érdekében Terápiarefrakter panaszok és kiterjedt iszkémia esetén intervenció

Nagy kockázatú obstruktív (>50\% szükület) koszorúér-betegség

\section{Javasolt teendö, mérlegelendő beavatkozás}

Életmódbeli változtatások, statin, aszpirin

Iszkémia elleni gyógyszeres terápia a panaszok csökkentése érdekében Intervenció mérlegelendő
A kalciumtartalom növekedése egyik csoportban sem mutatott korrelációt a lipoprotein- vagy a CRP-szinttel. A statinterápia tehát hozzájárul - a plakk-regressziót okozó hatásától függetlenül - a koszorúér-plakkok kalcifikációjához, azaz a plakkok stabilizálódásához. Ezen megfigyelés ismeretében a szekunder prevencióban részesülő betegek esetleges után követésére a Ca-score értéke önmagában nem alkalmas (30).

Az ISCHEMIA és DISCHARGE nemzetközi vizsgálatok befejezését kiemelt figyelem kíséri, mindkét vizsgálat fontos eredményeket hozhat a stabil anginával rendelkező betegek kivizsgálását és kezelését illetően. Az ISCHEMIA-vizsgálatba az iszkémia provokációs teszten legalább közepes fokú iszkémiát mutató betegek kerülnek beválasztásra. Minden betegnél történik koronária-CT-angiográfia és amennyiben obstruktív betegség igazolódik, de az nem a bal fötörzset érinti, a betegek randomizációra kerülnek, konzervatív terápia vagy invazív angiográfia ágra.

A DISCHARGE-vizsgálatba olyan közepes rizikójú, stabil anginás betegek kerülnek beválasztásra, akiknél invazív angiográfiára klinikai indikációja áll fenn. A betegek a beválasztás után invazív angiográfia vagy koronária-CT-angiográfia ágra randomizálódnak. A DISCHARGE a koronária-CT-angiográfia „kapuőr” szerepét vizsgálja az invazív vizsgálat előtt.

\section{Az American Heart Association (AHA) ajánlása}

Az AHA 2013-ban közzé tett ajánlásában a Ca-score meghatározását a kockázatbesorolást pontosító leg- hasznosabb vizsgálatnak ítélték azon betegek esetében, akiket a standard rizikóbecslés a közepes kategóriába sorolt (31). A Ca-score alapján történő rizikóbecslés pontosabbnak bizonyult, mint a CRP vagy más biomarkerek fehasználásával végzett rizikóbesorolás (32). Már a 2010ben publikált AHA-ajánlásban közepes rizikójú, panaszmentes egyének kardiovaszkuláris rizikóbecslésére Ila szintű ajánlásként szerepelt a Ca-score vizsgálata (33). A Ca-score értéke a erős független prediktornak bizonyult az általános populációban, az idősekben és a cukorbetegekben is. Az AHA-ajánlás külön kiemeli, hogy a Ca-score alapján nemcsak az anti-ateroszklerotikus terápiára állítandó betegek azonosíthatók, hanem a kalcifikáció nélküli betegek esetében kiderül az, hogy kiknél nincs szükség statin- és/vagy aszpirinterápiára (34).

\section{A NICE ajánlása}

A National Institute for Health and Care Excellences (NICE) a legújabb ajánlását kiegészítette 2017 márciusában, amelyben negatív kardiovaszkuláris anamnézissel rendelkező új keletű anginás betegek nem invazív kivizsgálását elemezték költséghatékonyság szempontjából (27). A stabil anginával jelentkező betegeknél a koronária-CTA-vizsgálatot alacsony ára és magas szenzitivitása, valamint az alacsony szövődményráta miatt elsővonalbeli tesztnek ítélték, és ezért az Egyesült Királyságon belül a következő években a vizsgálatok számának 700\%-os növekedését várják (35). Fontos kiemelni, hogy a koronária-CTA anatómiai diagnózist nyújt, funkcionális információt önmagában nem hordoz. A koronária-CTA dobutamin stressz-echokardiográfiával kiegészítve azonban a költséghatékonyság terén a második volt a sorban az Egyesült Királyságban (35). A NICE irányelve alapján a koronária-CTA-vizsgálatnak „kapuőr” szerepet kellene betölteni az invazív angiográfiára kerülők betegek esetében.

\section{Jo̊vő́beni fejlesztési irányok}

A koronária-CTA több mint tizenöt éves múlttal rendelkezik a koszorúér-betegség azonosításában és a szükület mértékének meghatározásában. A koronária-CTA legújabb fejlesztési irányai nagy hangsúlyt fektetnek arra, hogy a vizsgálatból funkcionális információ is kinyerhető legyen. A koronária-CTA által ábrázolt anatómiai információt computational fluid dinamikával kombinálva Frakcionális Flow Rezerv (FFR) értékhez juthatunk. A CT-alapú FFR-értékek invazív vizsgálat nélkül segítenek azonosítani a lézióspecifikus iszkémiát, mindezt három dimenzióban, a teljes koszorúér-rendszerre vonatkozóan. A mérés elvégzéséhez elegendő a koronária-CTA-felvétel önmagában. Az FFR-CT-vizsgálattal tovább erősödne a koronária-CTA „kapuőr” szerepe az invazív angiográfia előtt (36). 


\section{Irodalom}

1. Task Force Members, Montalescot G, Sechtem U, et al. 2013 ESC guidelines on the management of stable coronary artery disease. Eur Heart J 2013; 34(38): 2949-3003. doi:10.1093/eurheartj/eht296.

2. Genders TSS, Meijboom WB, Meijs MFL, et al. CT coronary angiography in patients suspected of having coronary artery disease: decision making from various perspectives in the face of uncertainty. Radiology 2009; 253(3): 734-744. doi:10.1148/radiol.2533090507.

3. Paech DC, Weston AR. A systematic review of the clinical effectiveness of 64-slice or higher computed tomography angiography as an alternative to invasive coronary angiography in the investigation of suspected coronary artery disease. BMC Cardiovasc Disord 2011; 11(1): 32. doi:10.1186/1471-2261-11-32.

4. Agatston AS, Janowitz WR, Hildner FJ, et al. Quantification of coronary artery calcium using ultrafast computed tomography. J Am Coll Cardiol 1990; 15(4): 827-832. http://www.ncbi.nlm.nih.gov/pubmed/2407762. Accessed February 22, 2016.

5. O'Rourke RA, Brundage BH, Froelicher VF, et al. American College of Cardiology/American Heart Association Expert Consensus document on electron-beam computed tomography for the diagnosis and prognosis of coronary artery disease. Circulation 2000; 102(1): 126-140. http://www. ncbi.nlm.nih.gov/pubmed/10880426. Accessed February 7, 2018.

6. Budoff MJ, Shaw LJ, Liu ST, et al. Long-term prognosis associated with coronary calcification: observations from a registry of 25,253 patients. J Am Coll Cardiol 2007; 49(18): 1860-1870. doi:10.1016/j. jacc.2006.10.079.

7. Blaha MJ, Cainzos-Achirica M, Greenland P, et al. Role of Coronary Artery Calcium Score of Zero and Other Negative Risk Markers for Cardiovascular Disease: The Multi-Ethnic Study Of Atherosclerosis (MESA). Circulation 2016; 133(9): 849-858. doi:10.1161/CIRCULATIONAHA.115.018524

8. Kalia NK, Cespedes L, Youssef G, et al. Motivational effects of coronary artery calcium scores on statin adherence and weight loss. Coron Artery Dis 2015; 26(3): 225-230. doi:10.1097/MCA.0000000000000207. 9. Criqui $\mathrm{MH}$, Denenberg $\mathrm{JO}, \mathrm{Ix} \mathrm{JH}$, et al. Calcium Density of Coronary Artery Plaque and Risk of Incident Cardiovascular Events. JAMA 2014; 311(3): 271. doi:10.1001/jama.2013.282535.

10. Zeb I, Budoff M. Coronary Artery Calcium Screening: Does it Perform Better than Other Cardiovascular Risk Stratification Tools? Henein M, ed. Int J Mol Sci 2015; 16(3): 6606-6620. doi:10.3390/ijms16036606. 11. Martin SS, Blaha MJ, Blankstein R, et al. Dyslipidemia, coronary artery calcium, and incident atherosclerotic cardiovascular disease: Implications for statin therapy from the multi-ethnic study of atherosclerosis. Circulation 2014; 129(1): 77-86. doi:10.1161/CIRCULATIONAHA.113.003625.

12. de Carvalho MSL, de Araujo Goncalves P, Garcia-Garcia HM, et al. Prevalence and predictors of coronary artery disease in patients with a calcium score of zero. Int J Cardiovasc Imaging 2013; 29(8): 1839-1846. doi:10.1007/s10554-013-0267-x.

13. Budoff $M J$, Dowe $D$, Jollis JG, et al. Diagnostic performance of 64-multidetector row coronary computed tomographic angiography for evaluation of coronary artery stenosis in individuals without known coronary artery disease: results from the prospective multicenter ACCURACY (Assessment by Coronary Computed Tomographic Angiography of Individuals Undergoing Invasive Coronary Angiography) trial. J Am Coll Cardiol 2008; 52(21): 1724-1732. doi:10.1016/j.jacc.2008.07.031.

14. Maurovich-Horvat P. A coronariák CT-angiográfiás vizsgálatának leletezése. Magy Radiológia Online 2013; 4(11). doi:10.5374/ mro.2013.11.01.

15. Bittencourt MS, Hulten E, Ghoshhajra B, et al. Prognostic value of nonobstructive and obstructive coronary artery disease detected by coronary computed tomography angiography to identify cardiovascular events. Circ Cardiovasc Imaging 2014; 7(2): 282-291. doi:10.1161/CIRCIMAGING.113.001047.

16. Drobni ZD, Karady J, Maurovich-Horvat P. Szív-CT szerepe a cardiovascularis rizikóbecslésben. Magy Családorvosok Lapja 2015; 5.

17. Karady J, Drobni ZD, Kolossvary M, et al. Non-invasive assessment of coronary plaque morphology. Curr Radiol Rep 2015; 3(36).

18. Maurovich-Horvat $P$, Ferencik $M$, Voros $S$, et al. Comprehensive plaque assessment by coronary CT angiography. Nat Rev Cardiol 2014; 11(7): 390-402. doi:10.1038/nrcardio.2014.60.

19. Tesche $\mathrm{C}$, Plank F, De Cecco $\mathrm{CN}$, et al. Prognostic implications of coronary CT angiography-derived quantitative markers for the prediction of major adverse cardiac events. J Cardiovasc Comput Tomogr 2016; 10(6): 458-465. doi:10.1016/j.jcct.2016.08.003.
20. Feuchtner G, Kerber J, Burghard P, et al. The high-risk criteria low-attenuation plaque \&lt;60 $\mathrm{HU}$ and the napkin-ring sign are the most powerful predictors of MACE: a long-term follow-up study. Eur Hear J - Cardiovasc Imaging 2017; 18(7): 772-779. doi:10.1093/ehjci/jew167. 21. Maurovich-Horvat $P$, Schlett $C L$, Alkadhi $H$, et al. The napkin-ring sign indicates advanced atherosclerotic lesions in coronary CT angiography. JACC Cardiovasc Imaging 2012; 5(12): 1243-1252. doi:10.1016/j. jcmg.2012.03.019.

22. Varnava AM, Mills PG, Davies MJ. Relationship between coronary artery remodeling and plaque vulnerability. Circulation 2002; 105(8): 939-943. http://www.ncbi.nlm.nih.gov/pubmed/11864922. Accessed February 7, 2018.

23. Motoyama S, Sarai M, Harigaya $\mathrm{H}$, et al. Computed tomographic angiography characteristics of atherosclerotic plaques subsequently resulting in acute coronary syndrome. J Am Coll Cardiol 2009; 54(1): 49-57. doi:10.1016/j.jacc.2009.02.068

24. Ayoub $C$, Erthal F, Abdelsalam MA, et al. Prognostic value of segment involvement score compared to other measures of coronary atherosclerosis by computed tomography: A systematic review and meta-analysis. J Cardiovasc Comput Tomogr 2017; 11(4): 258-267. doi:10.1016/j. jcct.2017.05.001.

25. Bittencourt MS, Hulten E, Ghoshhajra B, et al. Prognostic value of nonobstructive and obstructive coronary artery disease detected by coronary computed tomography angiography to identify cardiovascular events. Circ Cardiovasc Imaging 2014; 7(2): 282-291. doi:10.1161/CIRCIMAGING.113.001047.

26. Andreini D, Pontone G, Mushtaq S, et al. A long-term prognostic value of coronary CT angiography in suspected coronary artery disease. JACC Cardiovasc Imaging 2012; 5(7): 690-701. doi:10.1016/j. jcmg.2012.03.009.

27. Moss AJ, Williams MC, Newby DE, et al. The Updated NICE Guidelines: Cardiac CT as the First-Line Test for Coronary Artery Disease. Curr Cardiovasc Imaging Rep 2017; 10(5): 15. doi:10.1007/s12410-0179412-6.

28. Zeb I, Li D, Nasir K, et al. Effect of statin treatment on coronary plaque progression - A serial coronary CT angiography study. Atherosclerosis 2013; 231(2): 198-204. doi:10.1016/j.atherosclerosis.2013.08.019.

29. Hulten E, Bittencourt MS, Singh A, et al. Coronary artery disease detected by coronary computed tomographic angiography is associated with intensification of preventive medical therapy and lower low-density lipoprotein cholesterol. Circ Cardiovasc Imaging 2014; 7(4): 629-638. doi:10.1161/CIRCIMAGING.113.001564.

30. Puri R, Nicholls SJ, Shao M, et al. Impact of statins on serial coronary calcification during atheroma progression and regression. J Am Coll Cardiol 2015; 65(13): 1273-1282. doi:10.1016/j.jacc.2015.01.036. 31. Goff DC, Lloyd-Jones DM, Bennett G, et al. 2013 ACC/AHA Guideline on the Assessment of Cardiovascular Risk. J Am Coll Cardiol 2014; 63(25): 2935-2959. doi:10.1016/j.jacc.2013.11.005.

32. Patel AA, Budoff MJ. Screening for heart disease: C-reactive protein versus coronary artery calcium. Expert Rev Cardiovasc Ther 2010; 8(1): 125-131. doi:10.1586/erc.09.166.

33. Greenland P, Alpert JS, Beller GA, et al. 2010 ACCF/AHA guideline for assessment of cardiovascular risk in asymptomatic adults: executive summary: a report of the American College of Cardiology Foundation/ American Heart Association Task Force on Practice Guidelines. Circulation. 2010;122(25):2748-2764. doi:10.1161/CIR.0b013e3182051bab. 34. Peters SAE, den Ruijter HM, Bots $M L$, et al. Improvements in risk stratification for the occurrence of cardiovascular disease by imaging subclinical atherosclerosis: a systematic review. Heart 2012; 98(3): 177184. doi:10.1136/heartjnl-2011-300747.

35. Strickland N. The challenge of national CT Coronary Angiography (CTCA) provision in response to NICE CG95 update 2016 Professor Huon Gray. www.bsci.org.uk. Accessed February 7, 2018.

36. Nakanishi R, Budoff MJ. Noninvasive FFR derived from coronary CT angiography in the management of coronary artery disease: technology and clinical update. Vasc Health Risk Manag 2016; 12: 269-278. doi:10.2147/VHRM.S79632.

37. Bittencourt MS, Hulten EA, Veeranna V, et al. Coronary Computed Tomography Angiography in the Evaluation of Chest Pain of Suspected Cardiac Origin. Circulation 2016; 133(20): 1963-1968. doi:10.1161/CIRCULATIONAHA 116.017593.

38. Divakaran S, Cheezum MK, Hulten EA, et al. Use of cardiac CT and calcium scoring for detecting coronary plaque: implications on prognosis and patient management. Br J Radiol 2015; 88(1046): 20140594. doi:10.1259/bjr.20140594 